\title{
ISOLATION AND STRUCTURAL ELUCIDATION OF FLAVONOLIGNAN DERIVATIVE FROM Melochia corchorifolia: EVALUATION OF THEIR BIOLOGICAL, ANTICANCER ACTIVITY AND MOLECULAR DOCKING STUDIES
}

\author{
M. Vinoth ${ }^{1,2}$ and B. Natarajan ${ }^{1, \bowtie}$ \\ ${ }^{1}$ Department of Chemistry, SRM Institute of Science and Technology, Kattankulathur 603203 , \\ (Tamil Nadu) India \\ ${ }^{2}$ Department of Chemistry, Dhanalakshmi Srinivasan College of Engineering and Technology, \\ Mamallapuram 603 104, (Tamil Nadu) India \\ ${ }^{\square}$ Corresponding Author: balanattunet@gmail.com
}

\begin{abstract}
Ethanolic extract of leaves Melochia corchorifolia subjected to silica gel column chromatography and the compounds obtained are analyzed for antioxidant activity. Among the compounds collected and tested, compound four showed a maximum antioxidant potential of $90.74 \pm 0.65 \%$ by DPPH activity. Flavonolignan, a flavonoid derivative compound, was isolated and structurally characterized using various spectral analyses. The antimicrobial activity of the compound showed maximum activity of $16 \mathrm{~mm}$ and $20 \mathrm{~mm}$ in $75 \mu \mathrm{g} / \mathrm{ml}$ and $100 \mu \mathrm{g} / \mathrm{ml}$ concentrations against the human pathogenic microorganisms. Molecular docking studies of the compound showed better binding affinity and $\mathrm{H}$-bond interaction with the human breast cancer estrogen receptor (3EQM) with binding energy of about $-9.91 \mathrm{kcal} / \mathrm{mol}$. We observed that the isolated compound showed a potent anticancer effect against MCF-7 cells from the preliminary results.

Keywords: Melochia corchorifolia, Spectroscopic Techniques, Antimicrobial, MCF-7 Cell, Flavonolignan Derivative, Antioxidant Activity.
\end{abstract}

RASĀYAN J. Chem., Vol. 14, No.3, 2021

\section{INTRODUCTION}

The emergence of new pathogens along with antibiotic resistance and the rising failure of chemotherapy is the biggest problem increasing mortality rate in tropical countries. The unavailability of vaccines for most of these diseases and the adverse side effects of chemotherapy enables us to find natural ways which can be used against the pathogens. ${ }^{1}$ The secondary metabolites are flavonoids, terpenoids, phenolic, tannins, and alkaloids compounds from plant origin are said to protect against the microbes as most of the compounds have antimicrobial and anti-inflammatory properties. They also effectively work as an antioxidant which prevents or slow down the damages of the free radicals or the unstable molecules that the body produces as a reaction and other pressures. These secondary metabolites are mainly synthesized from various parts of the plants such as leaf, root, stem, flower, fruit, twig, and seeds and are used to develop new novel drugs. ${ }^{2}$

Melochia corchorifolia (L.) is a perennial aromatic plant, mostly sighted in the wastelands. The leaves and roots of these plants, are utilized for treating several complications such as headache, ulcers, helminthiasis, abdominal swellings, food poisoning, and dysentery. ${ }^{3}$ Pharmacologically, the leaf extract has antioxidant, anticancer, antibacterial, antiurolithiatic, Anthelmintic, and antidiuretic activities. ${ }^{4}$ The Phytoconstituents analysis of $M$. corchorifolia leaves has exposed the presence triterpenes, flavonol, glycosides, flavonoids, $\beta$-D-glucoside, and alkaloids. ${ }^{5}$ The components such as cyclopeptide alkaloids franganine, adouetine-y, frangufoline, and novel cyclopeptide were identified and even chronicled earlier from this plant. ${ }^{6}$ Human breast cancer is the second most common cancer found among women due to their lifestyle changes such as dietary changes, late childbearing in developing countries leads to the riskfactor of cancer development. ${ }^{7}$ The MCF-7 cell line has proven to be a useful model of hormoneresponsive breast cancer. These cells contain receptors for both estrogen and progesterone and respond to Rasayan J. Chem., 14(3), 1669-1679(2021)

http://doi.org/10.31788/RJC.2021.1436431

This work is licensed under a CC BY 4.0 license. 
the addition of estrogen in vitro by an increase in the rate of cell proliferation and the induction of several specific proteins. The purpose of molecular docking is to obtain preliminary information about the affinity of any compound before the start of in-vitro experiments. ${ }^{8,9}$ In this study, ligand affinity was assessed by three parameters such as H-bonding energy, binding energy, and inhibition constant. ${ }^{10}$ The present study aimed to isolate a compound from antioxidant potential fraction obtain through column chromatography and screen for antimicrobial activity from the above aspects. Further, docking analysis was performed to study the binding energy of purified compounds against the human breast cancer estrogen receptor to control cell proliferation. Besides, the study was experimented with in vitro method by MTT assay on MCF-7 cells to analyze the anticancer activity.

\section{Extraction of Plant Leaves}

\section{EXPERIMENTAL}

The leaves of Melochia corchorifolia were washed, shade dried and finely powdered using a mechanical blender and extracted exhaustively by Soxhlet apparatus (8h) using ethanol at $60^{\circ} \mathrm{C}$ stored in an air-tight container for further use. ${ }^{11}$

\section{Silica Gel Column Chromatography}

The dried leaves Melochia corchorifolia $(500 \mathrm{~g})$ was ethanol refluxed using $1000 \mathrm{ml}$ and the extract was fractioned using silica gel column (100-200 mesh size) chromatography. The separation of the extract was carried out by successive elution with gradually increasing the polarity of the solvents from n-hexane and ethyl acetate. Pre-coated TLC plates were used for analyzing the purity and separation of the fractions. ${ }^{12}$

\section{Spectral Analysis}

A UV-Vis spectrophotometer (Shimadzu, Japan) was observed in the range of 200 to $800 \mathrm{~nm}$ at $25^{\circ} \mathrm{C}$ in ethanol. IR spectrum was recorded in Shimadzu-FTIR spectrometer using the KBr pellet. The spectrum of ${ }^{1} \mathrm{H}$ NMR $(500 \mathrm{MHz}){ }^{13} \mathrm{C}$ NMR $(125 \mathrm{MHz})$ was reported on a $5 \mathrm{~mm}$ TUBES $500 \mathrm{MHz}$ Bruker Avance II spectrometer using $\mathrm{CDCl}_{3}$ as a solvent and TMS as an internal standard (chemical shift in ppm). The regular recording of the DEPT135 spectrum $(\theta=135$ pulse program $)$ was performed. Using the standard Bruker pulse system, the 2D ${ }^{1} \mathrm{H}-{ }^{1} \mathrm{H}$ COSY and HSQC spectra recorded. HPLC was done in a Shimadzu LC solution equipped with the quaternary pump and UV-Vis spectrophotometer (Shimadzu, Japan). The column used for the study was C18 $(2504.6 \times 5 \mu \mathrm{m})$. The mobile phase was toluene: ethyl acetate: methanol (7:3:1) with the scanning wavelength at $260 \mathrm{~nm}$. Mass analysis was carried out by using Q-T of Mass Spectrometer (Micro mass) instrument with high-resolution double focus. Total resolution (6000), Daltons Source options- Electron impact (EI), calibrated Total mass (1500), chemical ionization (CI). ${ }^{13}$

\section{Antioxidant-DPPH Assay}

The DPPH assay is based on a stable free radical reduction method and maximum absorption at $517 \mathrm{~nm}$. The quantity of $4.3 \mathrm{mg} \mathrm{1,1-Diphenyl-2-picrylhydrazyl} \mathrm{was} \mathrm{dissolved} 3.3 \mathrm{~mL}$ ethanol and shielded from light by aluminum foil covering the test tubes. About $50 \mu \mathrm{L}$ concentrations $(10-100 \mu \mathrm{g} / \mathrm{mL})$ of ethanol extract leaf of Melochia corchorifolia with ascorbic acid were added and the volume solution was made uniformly to $150 \mu \mathrm{L}$ using ethanol followed by addition $150 \mu \mathrm{L}$ of DPPH. ${ }^{14}$ The absorbance was recorded at $517 \mathrm{~nm}$ using ethanol as blank. The value of the samples and standard and calculated the percentage of inhibition.

\section{High Performance Liquid Chromatography Analysis}

HPLC (Shimadzu LC) column was used for the study is C18250 $4.6 \times 5 \mu \mathrm{m}$. The mobile phase solvent was a 7:2:1 combination of toluene, ethyl acetate, and ethanol. ${ }^{15}$

\section{UV-Visible Spectra Analysis}

UV-Visible spectrum analysis performed in the range of 200 to $800 \mathrm{~nm}$, control ethanol was used. ${ }^{16}$

\section{In-vitro Activity-Antimicrobial Studies}

The agar well diffusion methodology was performed for human pathogenic bacteria organisms. The antimicrobial activity plates were concocted with $20 \mathrm{ml}$ of sterile Muller Hinton agar for bacteria. The 
solidified media was topped with the test culture and was left to dry for $10 \mathrm{~min}$. The sterile well borer was used to make wells in the seeded plates as soon as the solidification of media was done. Wells are filled with $25,50,75$, and $100 \mu \mathrm{g} / \mathrm{ml}$ of the compound flavonolignan derivative compound 4 , negative control as Streptomycin and Clotrimazole well served as a positive control. The plates are incubated at about $37^{\circ} \mathrm{C}$ for $24 \mathrm{~h}$ and activity was calculated in the range of diameter and zone of inhibition formed around the well. In antifungal activity, the same method as for bacteria was adopted, but potato dextrose agar (PDA) was used for both $C$. albicans and $A$. niger. The medium was incubated at $25^{\circ} \mathrm{C}$ for 2 days for $C$. albicans and 3 days for $A$. niger test. ${ }^{17}$

\section{MTT Assay}

The assay was executed using (3 (4, 5dimethyl thiazol-2yl) 2, 5 diphenyl tetrazolium bromide (MTT) (Sigma Aldrich, Bangalore). The MTT is partitioned by mitochondrial succinate dehydrogenase and followed by reductase in viable cells. That accumulates formazan for a measurable purple substance. Then following $48 \mathrm{~h}$ incubation, MTT assays were added in wells for $3 \mathrm{~h}$ and medium extracted from wells and $100 \mu 1$ of SDS were applied in DMSO to dissolve the formazan crystals and absorbance were read at $540 \mathrm{~nm} .{ }^{18}$

\section{Auto Docking Studies}

Auto dock 4.2 tools were used for docking to have a better understanding of the analysis. The human breast cancer estrogen receptor protein was subjected to forecast the mechanism of the purified compound. The PDB files were edited using chimera tools, non-protein compounds were removed, and receptor protein saved. Then PDB files edited by adding hydrogen and water molecules removed for accuracy. The docking analysis was performed with Auto dock scripts of ADT tools. ${ }^{19}$

\section{Antioxidant Activity}

\section{RESULTS AND DISCUSSION}

The compounds obtained from column chromatography were evaluated for DPPH assay, which showed that all the compounds possess free radical scavenging ability. The percentage of inhibition compounds lied between $80-90 \%$. Among all the compounds tested, compound 4 showed a remarkable antioxidant activity of $90.74 \pm 0.65 \%$ in Fig.-1 to scavenge DPPH radicals and hence the compound 4 was structurally elucidated. The DPPH ability to free radical scavenging of all compounds (C1-C5) is tabulated shown in Table-1.

Table-1: DPPH Assay of the Isolated Compounds

\begin{tabular}{|c|c|}
\hline \multicolumn{2}{|c|}{ Table-1: DPPH Assay of the Isolated Compounds } \\
\hline Compounds & DPPH Free Radical Scavenging* (\%) \\
\hline Compound 1 & $82.77 \pm 1.39$ \\
\hline Compound 2 & $79.30 \pm 1.19$ \\
\hline Compound 3 & $82.20 \pm 1.04$ \\
\hline Compound 4 & $90.74 \pm 0.65$ \\
\hline Compound 5 & $80.49 \pm 1.38$ \\
\hline
\end{tabular}

\section{FT-IR}

The flavonolignan derivative compound 4 spectral analyses showed in Fig.-2 Functional group peaks are tabulated in Table-2. The intense peak for hydroxyl group stretching vibration at $3377 \mathrm{~cm}^{-1}$ indicates the hydroxyl functional group. Then aromatic and aliphatic $\mathrm{C}-\mathrm{H}$ stretching frequency vibration showed at the range of 2961 and $2840 \mathrm{~cm}^{-1}$. The carbonyl and vinyl alkyl ether stretching vibration frequency was observed at the range 1650 and $1610 \mathrm{~cm}^{-1}$. The $\mathrm{C}-\mathrm{H}$ bending vibration showed at $1439 \mathrm{~cm}^{-1}$ and Hydroxyl $(\mathrm{OH})$ bending vibration at $1325 \mathrm{~cm}^{-1}$. The previous studies demonstrated that the alcoholic extracts would exhibit the FTIR spectra at 2900-3500 $\mathrm{cm}^{-1}$. This interprets the presence of $\mathrm{OH}$ and C-H vibrations with the flavonoids and phenolic compounds. ${ }^{20}$

\section{Spectroscopic Characterizations Flavonolignan Derivative}

${ }^{1} \mathrm{H}$ NMR spectrum flavonolignan derivative compound showed Fig.-3 aromatic methine protons at $\delta 7.62$ (s, 1H), $7.44(\mathrm{~s}, 1 \mathrm{H}), 7.19(\mathrm{~s}, 1 \mathrm{H}), 7.14(\mathrm{t}, J=10 \mathrm{~Hz}, 1 \mathrm{H}), 6.97(\mathrm{~d}, J=10 \mathrm{~Hz}, 1 \mathrm{H}), 6.81$ (d, $J=10 \mathrm{~Hz}$, 


\section{RASĀYAN $J$. Chem.}

Vol. 14 | No. 3 |1669-1679| July - September | 2021

$1 \mathrm{H}), 6.76(\mathrm{~d}, J=10 \mathrm{~Hz}, 1 \mathrm{H}), 6.55(\mathrm{~d}, J=10 \mathrm{~Hz}, 1 \mathrm{H}) \mathrm{ppm}$. The flavonoid ring methine protons were observed at 5.77-5.67 ppm as a multiplate. The aromatic attached hydroxyl protons were observed at $6.17 \mathrm{ppm}$. Five membered furan ring methylene proton were observed at the range is $4.92\left(\mathrm{dd}, J_{1,2}=10\right.$ $\mathrm{Hz}, 25 \mathrm{~Hz}), 4.28(\mathrm{~d}, J=5 \mathrm{~Hz}), 4.25(\mathrm{t}, J=10 \mathrm{~Hz}), 4.06(\mathrm{q}, J=10 \mathrm{~Hz}) \mathrm{ppm}$ multiplate respectively. Five membered furan ring methine proton were observed at the range is 3.66-3.50 multiplate.

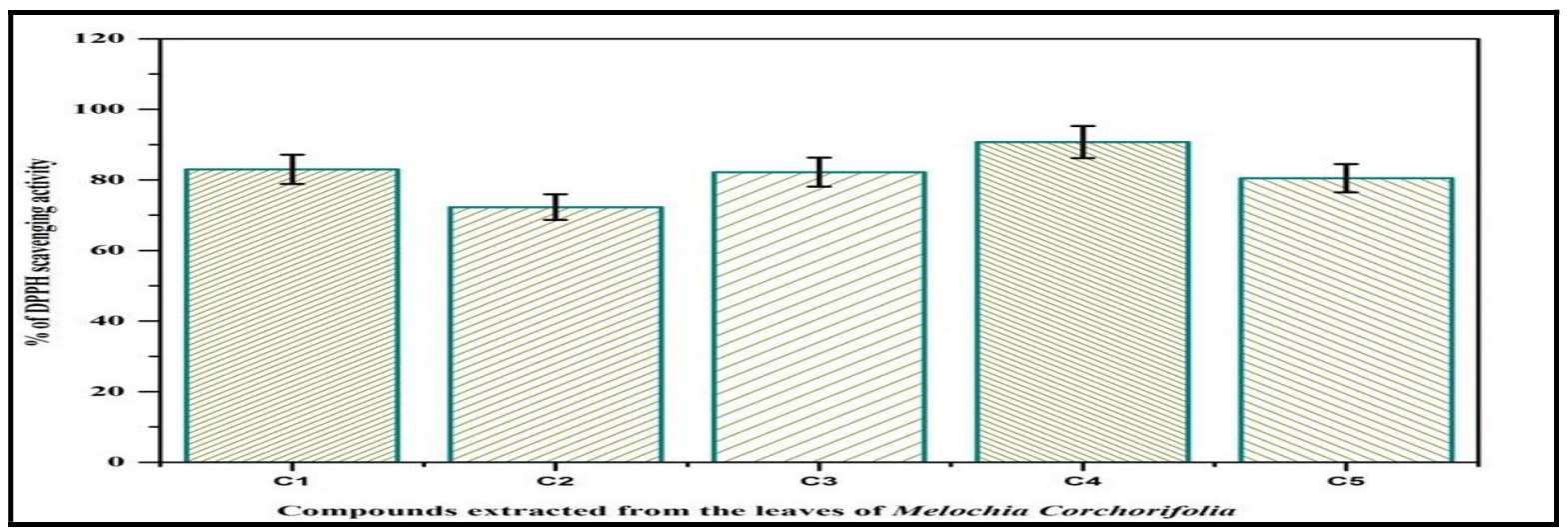

Fig.-1: DPPH Scavenging Activity against the isolated Compounds

Table-2: FT-IR Spectral Analysis Data of Purified Compound

\begin{tabular}{c|c|c}
\hline Peak Wavenumber $\mathrm{cm}^{-1}$ & Vibration Type & Functional Groups \\
\hline 3377 & $-\mathrm{O}-\mathrm{H}$ (stret) & Alcohol \\
\hline 2961 & $-\mathrm{C}-\mathrm{H}($ Ar stret) & Aliphatic \\
\hline 2840 & $-\mathrm{C}-\mathrm{H}\left(\mathrm{Sp}^{3}\right.$ stret) & Methylene \\
\hline 1650 & $-\mathrm{C}=\mathrm{O}$ (stret) & Carbonyl \\
\hline 1610 & $-\mathrm{C}=\mathrm{C}$ (stret) & Alkyl Ether \\
\hline 1439 & $-\mathrm{C}-\mathrm{H}$ (bend) & Aromatic \\
\hline 1325 & $-\mathrm{O}-\mathrm{H}$ (bend) & Alcohol \\
\hline
\end{tabular}

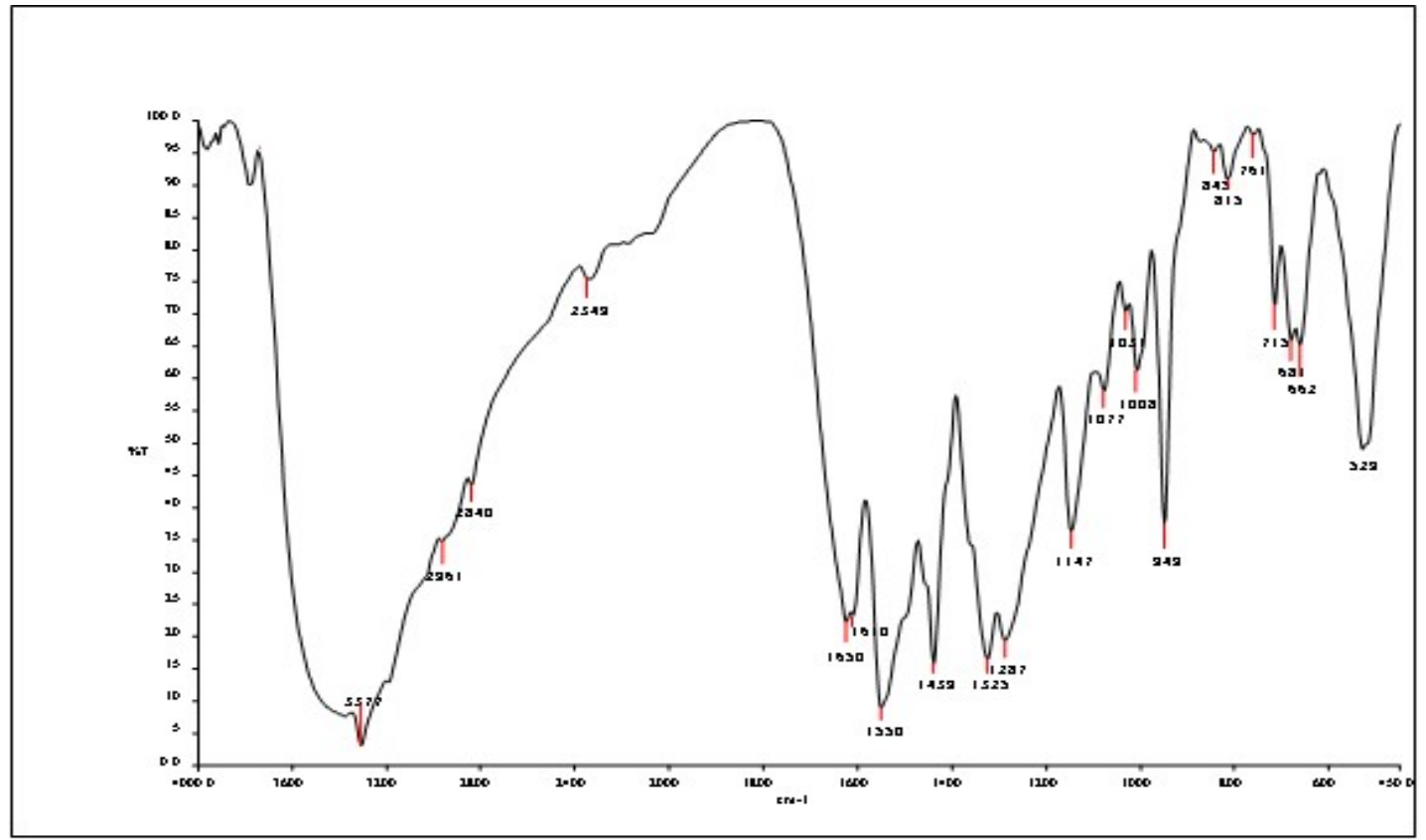

Fig.-2: FT-IR Spectrum of Flavonolignan Derivative

Aliphatic methylene proton was observed at the range at $\delta 2.00(\mathrm{~s}), 1.95(\mathrm{~s}), 1.32(\mathrm{~s}), 1.16-0.77(\mathrm{~m}) \mathrm{ppm}$ respectively. ${ }^{13} \mathrm{C}$ NMR of the flavonolignan derivative compound showed carbonyl carbon peak at 199.07 
RASĀYAN J. Chem.

Vol. 14 | No. 3 |1669-1679| July - September | 2021

respectively it shows flavanone group Fig.-4. The aromatic carbon signal observed at the range is $\delta$ 139.2, $130.9,129.5,128.8,123.9,123.3,120.1,115.8,115.3,114.0 \mathrm{ppm}$ and aliphatic carbon peak were observed at the range is $71.7,70.4,65.5,60.4,33.8,31.9,31.6,30.5,29.6,29.6,29.4,29.3,29.1,28.9$, 27.7, 22.6, 20.9, 20.6, 19.1, 19.1, 14.1, 14.0 ppm. ${ }^{1} \mathrm{H}$ NMR (500MHz, $\left.\mathrm{CDCl}_{3}, \mathrm{ppm}\right): \delta 7.62$ (s, 1H), 7.44 $(\mathrm{s}, 1 \mathrm{H}), 7.19(\mathrm{~s}, 1 \mathrm{H}), 7.14(\mathrm{t}, J=10 \mathrm{~Hz}, 1 \mathrm{H}), 6.97(\mathrm{~d}, J=10 \mathrm{~Hz}, 1 \mathrm{H}), 6.81(\mathrm{~d}, J=10 \mathrm{~Hz}, 1 \mathrm{H}), 6.76(\mathrm{~d}, J=$ $10 \mathrm{~Hz}, 1 \mathrm{H}), 6.55(\mathrm{~d}, J=10 \mathrm{~Hz}, 1 \mathrm{H}), 5.77-5.67(\mathrm{~m}, 1 \mathrm{H}), 4.92\left(\mathrm{dd}, J_{l, 2}=10 \mathrm{~Hz}, 25 \mathrm{~Hz}, 2 \mathrm{H}\right), 4.28(\mathrm{~d}, J=5$ $\mathrm{Hz}, 1 \mathrm{H}), 4.25(\mathrm{t}, J=10 \mathrm{~Hz}, 2 \mathrm{H}), 4.06(\mathrm{q}, J=10 \mathrm{~Hz}, 17 \mathrm{H}), 3.66-3.50(\mathrm{~m}, 3 \mathrm{H}), 2.00(\mathrm{~s}, 9 \mathrm{H}), 1.95(\mathrm{~s}, 17 \mathrm{H})$, $1.32(\mathrm{~s}, 3 \mathrm{H}), 1.16-0.77(\mathrm{~m}, 62 \mathrm{H}){ }^{13} \mathrm{C}$ NMR Data $\left(125 \mathrm{MHz}, \mathrm{CDCl}_{3}, \mathrm{ppm}\right): \delta 199.07176 .46,171.34$, $139.23,130.91,129.50,128.83,123.91,123.39,120.18,115.81,115.32,114.04,71.73,70.47,65.59$, $60.45,33.80,31.90,31.60,30.54,29.67,29.60,29.49,29.33,29.13,28.93,27.70,22.66,20.99,20.67$, $19.15,19.12,14.14,14.07$ ppm DEPT $135 \mathrm{NMR}\left(125 \mathrm{MHz}, \mathrm{CDCl}_{3}, \mathrm{ppm}\right): \delta 139.24,131.05,128.85$, $114.05,60.46,60.44,33.80,31.91,31.60,29.68,29.61,29.47,29.34,29.14,28.94,22.67,21.03,20.69$, $19.12,14.15,14.08 \mathrm{ppm}$. Investigation of the correlations in the COSY spectrum further assisted to elucidate the structure of the compound 4 one bond coupling with carbon and hydrogen was observed in HSQC. HSQC was used to obtain the complete assignment of proton and carbon resonances. From the HSQC correlations, the aromatic and furan ring moiety couplings are confirmed and shown in the Table3 , the long-range correlation of aromatic methine and furan ring moiety methine protons in the compound 4 as showed in DEPT 135 spectrum of flavonolignan compound 4 Fig.- $5 .{ }^{1} \mathrm{H}-{ }^{1} \mathrm{H}$ COSY NMR Spectrum of flavonolignan compound 4 is shown in Fig. -6 and HSQC Spectrum of flavonolignan compound 4 is shown in Fig.-7. NMR chemical shifts together with 2D NMR correlations confirm that the predicted molecular structure is flavonolignan derivative compound 4 which is in consistent with proposed structure of the flavonolignan derivative. The Mass spectral analysis flavonolignan compound 4 showed Fig. 8 the intense base peak at 301.2852 is because of the presence of taxifolin, a flavonoid moiety and $(\mathrm{M}+1)^{+}$ molecular ion peak at 713.8269 , the molecular mass of compound 4 and corresponds to the calculated theoretical molecular mass of the isolated compound $\mathrm{m} / \mathrm{z} ; 712.2520$. The HR-MS, flavonolignan derivative compound 4 deduced is molecular formula $\mathrm{C}_{40} \mathrm{H}_{40} \mathrm{O}_{12}$ and name (2R,3R)-2-(5'((1S,3aR,4S,6aR)-4-(4-(hex-5-en-1-yl)-3-methoxyphenyl)hexahydrofuro[3,4-c]furan-1-yl)-2',3',5,6tetrahydroxy-[1,1'-biphenyl]-3-yl)-3,5,7-trihydroxychroman-4-one, Fig.-9. ${ }^{21}$

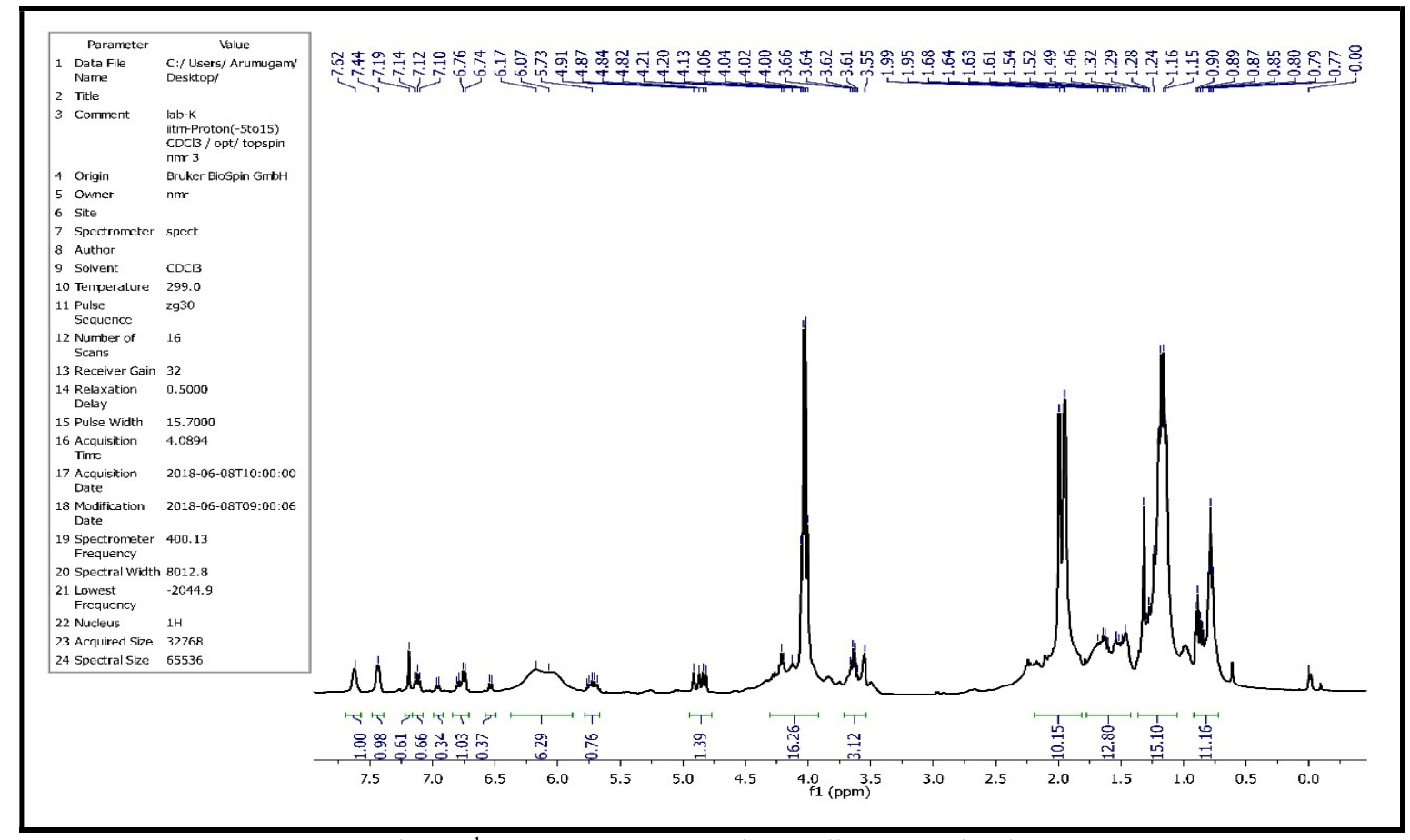

Fig.-3: ${ }^{1} \mathrm{H}$ NMR Spectrum Flavonolignan Derivative 


\section{RASĀYAN J. Chem.}

Vol. 14 | No. 3 |1669-1679| July - September | 2021

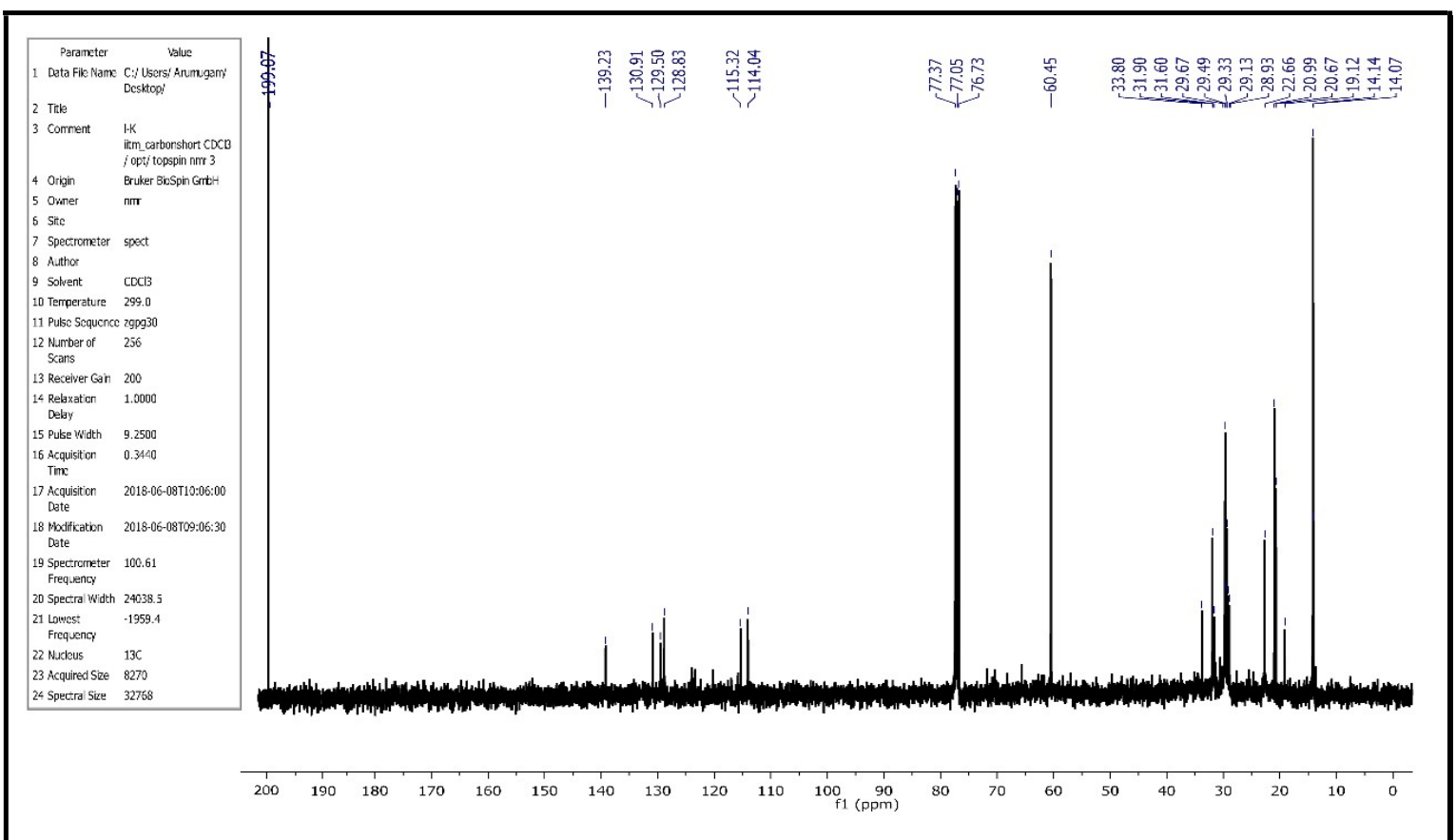

Fig.-4: ${ }^{13} \mathrm{C}$ NMR Spectrum Flavonolignan Derivative

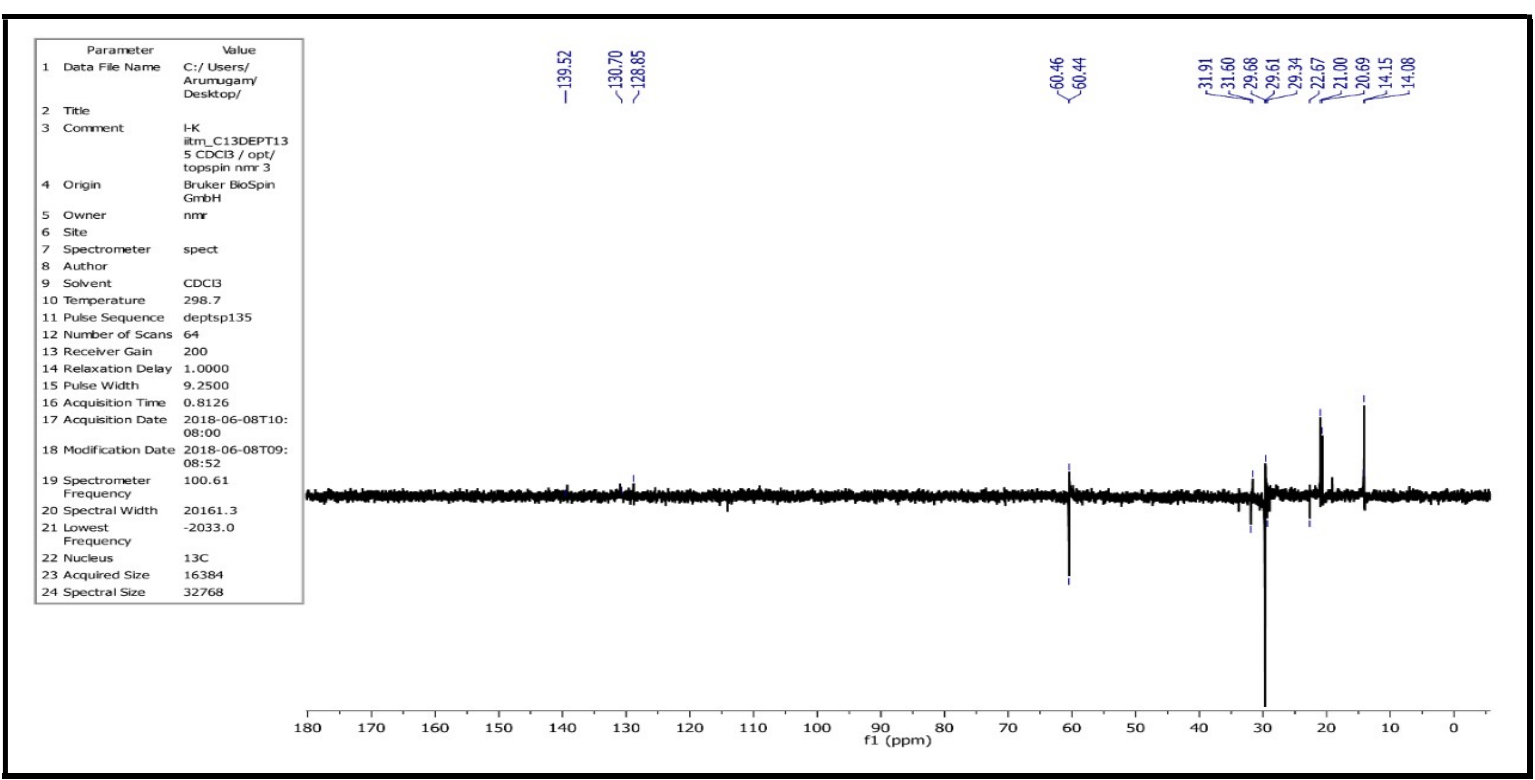

Fig.-5: DEPT 135 Spectrum Flavonolignan Derivative

Table-3: ${ }^{1} \mathrm{H}$ NMR, ${ }^{1} \mathrm{H}-{ }^{1} \mathrm{H}$ COSY, HSQC NMR $\left({ }^{1} \mathrm{~J}\right)$ Data of Purified Flavonolignan Derivative

\begin{tabular}{c|c|c}
\hline Proton Number $\left({ }^{1} \mathrm{H}\right.$ NMR $)$ & ${ }^{1} \mathrm{H}-{ }^{1} \mathrm{H}$ Cosy & HSQC NMR $\left({ }^{1} J\right)$ \\
\hline $\mathrm{H} 1-7.62(\mathrm{~s}, 1 \mathrm{H})$ & $\mathrm{H} 1-\mathrm{H} 2$ & 128.70 \\
\hline $\mathrm{H} 2-7.44(\mathrm{~s}, 1 \mathrm{H})$ & $\mathrm{H} 2-\mathrm{H} 1$ & 130.94 \\
\hline $\mathrm{H} 3-7.19(\mathrm{~s}, 1 \mathrm{H})$ & & 123.84 \\
\hline $\mathrm{H} 4-7.14(\mathrm{t}, J=10 \mathrm{~Hz}, 1 \mathrm{H})$ & $\mathrm{H} 4-\mathrm{H} 6, \mathrm{H} 7$ & 123.33 \\
\hline $\mathrm{H} 5-6.97(\mathrm{~d}, J=10 \mathrm{~Hz}, 1 \mathrm{H})$ & $\mathrm{H} 5-\mathrm{H} 8$ & 120.26 \\
\hline $\mathrm{H} 6-6.81(\mathrm{~d}, J=10 \mathrm{~Hz}, 1 \mathrm{H})$ & $\mathrm{H} 6-\mathrm{H} 4$ & 115.31 \\
\hline $\mathrm{H} 7-6.76(\mathrm{~d}, J=10 \mathrm{~Hz}, 1 \mathrm{H})$ & $\mathrm{H} 7-\mathrm{H} 4$ & 115.79 \\
\hline $\mathrm{H} 8-6.55(\mathrm{~d}, J=10 \mathrm{~Hz}, 1 \mathrm{H})$ & $\mathrm{H} 8-\mathrm{H} 3$ & 139.14 \\
\hline $\mathrm{H} 9-5.77-5.67(\mathrm{~m}, 1 \mathrm{H})$ & $\mathrm{H} 9-\mathrm{H} 10$ & $114.12,114.03$
\end{tabular}




\section{RASĀYAN J. Chem.}

Vol. 14 | No. 3 |1669-1679| July - September | 2021

\begin{tabular}{c|c|c}
\hline $\mathrm{H} 11-4.28(\mathrm{~d}, J=5 \mathrm{~Hz}, 1 \mathrm{H})$ & $\mathrm{H} 11-\mathrm{H} 19$ & 61.57 \\
\hline $\mathrm{H} 12-4.25(\mathrm{t}, J=10 \mathrm{~Hz}, 2 \mathrm{H})$ & $\mathrm{H} 12-\mathrm{H} 17$ & 65.53 \\
\hline $\mathrm{H} 13-4.06(\mathrm{q}, J=10 \mathrm{~Hz}, 17 \mathrm{H})$ & $\mathrm{H} 13-\mathrm{H} 19$ & 60.39 \\
\hline $\mathrm{H} 14-3.66-3.50(\mathrm{~m}, 3 \mathrm{H})$ & $\mathrm{H} 14-\mathrm{H} 19$ & $70.36,47.91,41.23,44.16$ \\
\hline $\mathrm{H} 15-2.00(\mathrm{~s}, 9 \mathrm{H})$ & $\mathrm{H} 15-\mathrm{H} 16$ & 20.63 \\
\hline $\mathrm{H} 16-1.95(\mathrm{~s}, 17 \mathrm{H})$ & $\mathrm{H} 16-\mathrm{H} 15$ & 20.92 \\
\hline
\end{tabular}

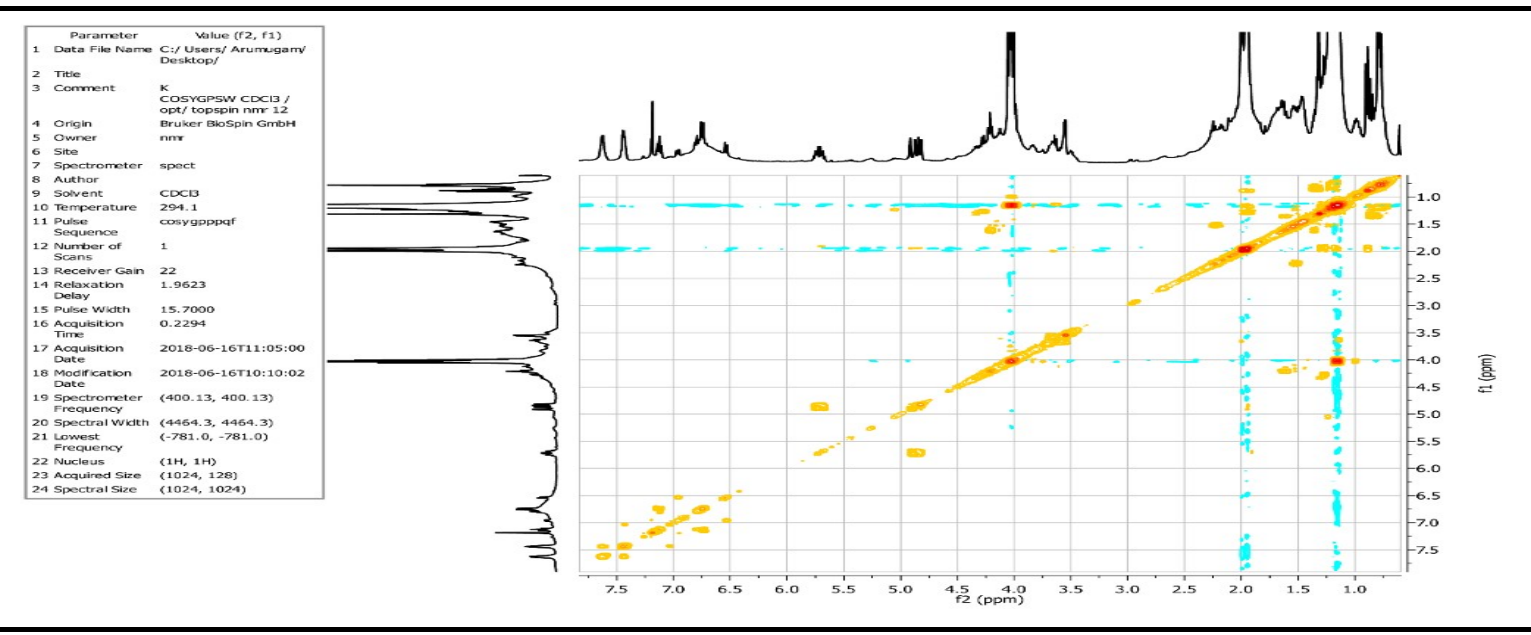

Fig.-6: ${ }^{1} \mathrm{H}-{ }^{1} \mathrm{H}$ COSY Spectrum Flavonolignan Derivative

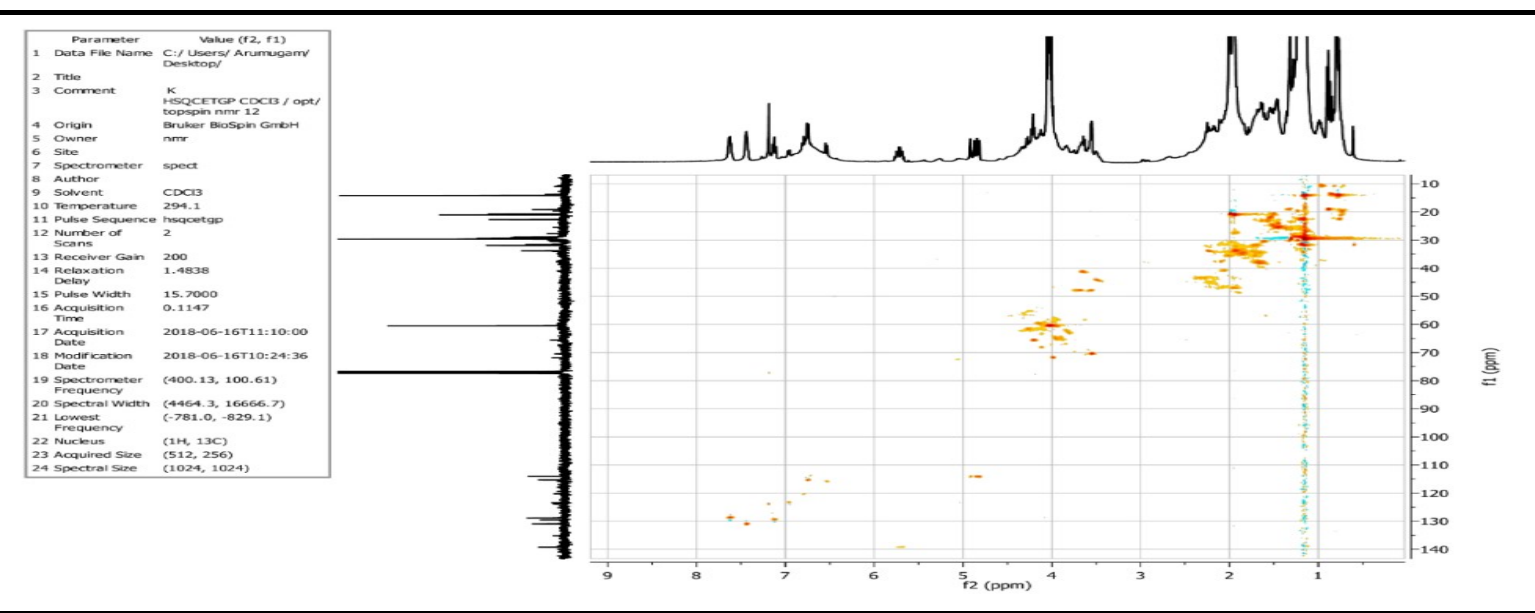

Fig.-7: HSQC Spectrum Flavonolignan Derivative

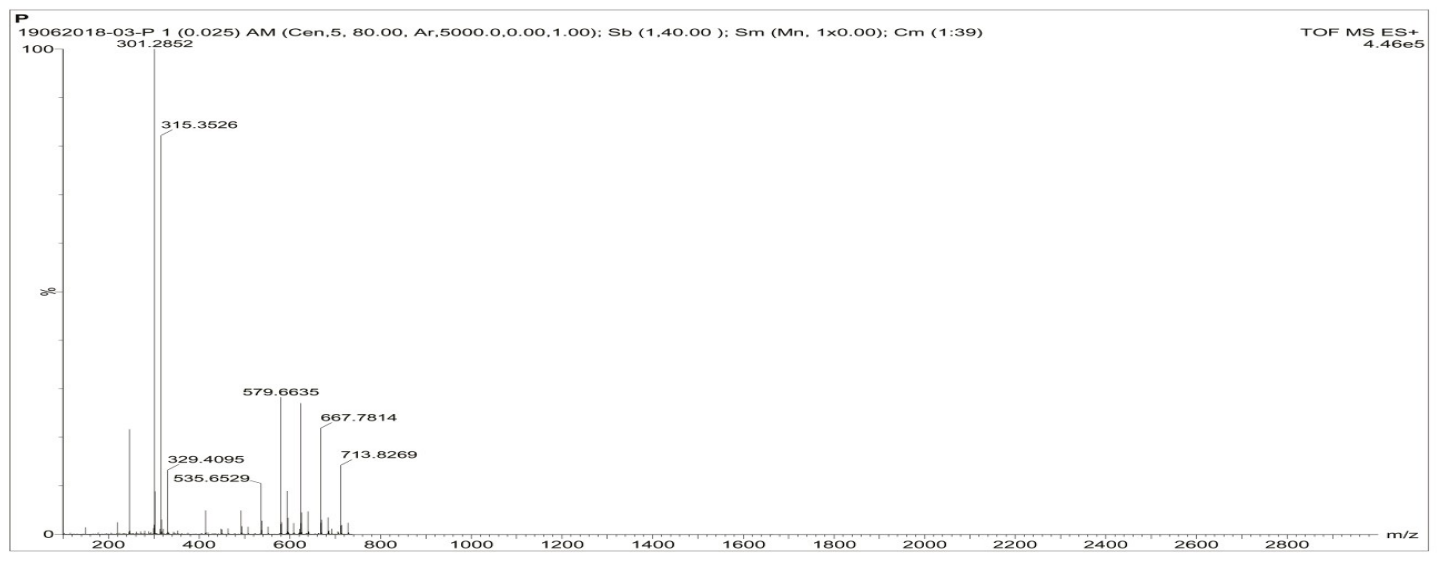

Fig.-8: Mass Spectrum of isolated Compound 4 


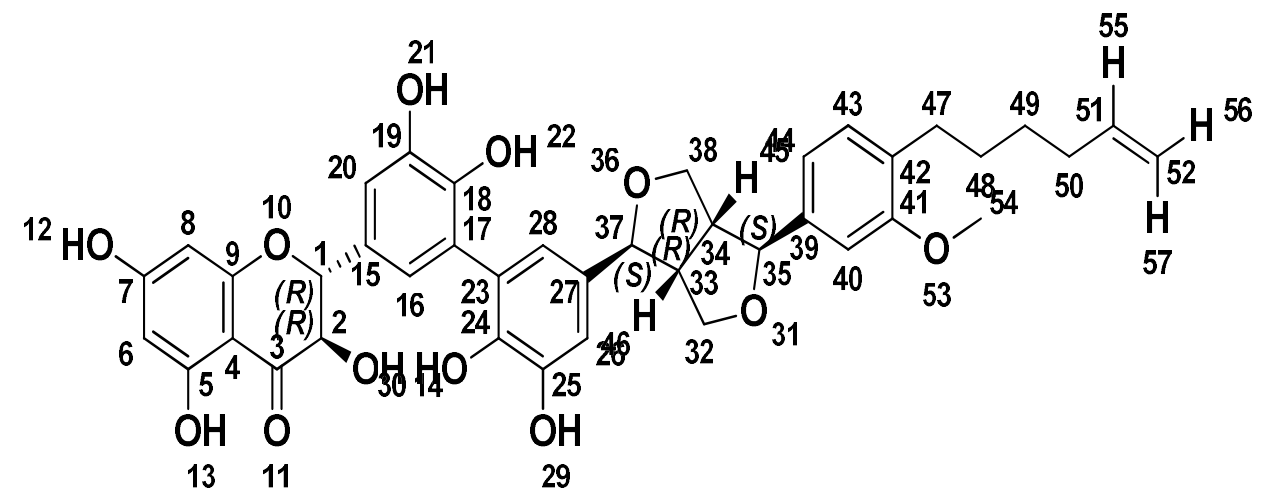

(2R, 3R)-2-(5'-((1S,3aR,4S,6aR)-4-(4-(hex-5-en-1-yl)-3-methoxyphenyl) hexahydrofuro[3,4-c] furan-1-yl)-2',3',5,6tetrahydroxy-[1,1'-biphenyl]-3-yl)-3,5,7-trihydroxychroman-4-one

\section{HPLC Analysis}

Fig.-9: Proposed Structure of the Compound 4

The purified compound showed a sharp peak at $9.945 \mathrm{~min}$ (retention time). The peak area is 42857 coverage of 100\% flavonolignan derivative compound 4, Fig.-10.

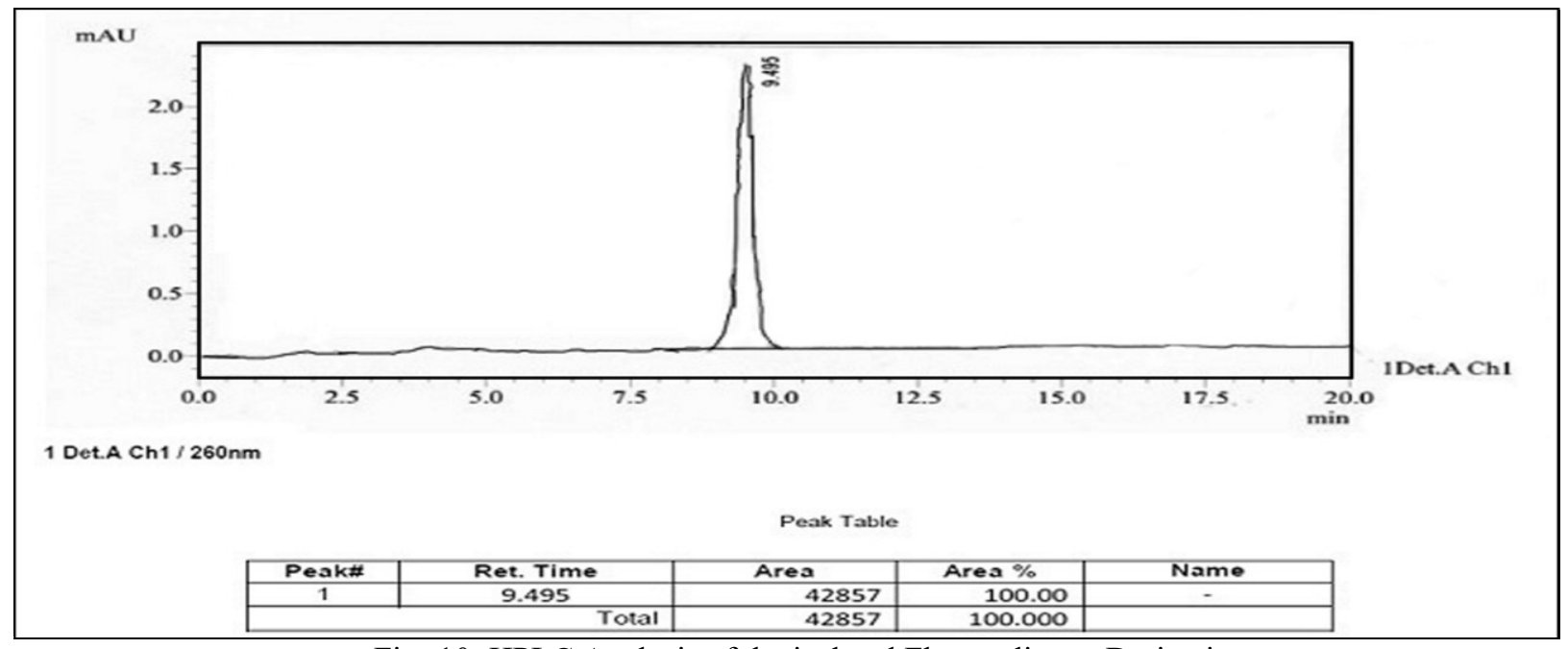

Fig.-10: HPLC Analysis of the isolated Flavonolignan Derivative

\section{UV-Vis Spectrum of Purified Compound}

The spectrum of the purified flavonolignan derivative compound 4 in ethanol solution Fig.-11 exhibited maximum absorption at $\mathrm{UV}$ area $277 \mathrm{~nm}$, indicating flavonolignan derivative compound 4 containing flavanone and polyphenol group.

\section{In-vitro Antimicrobial Activity}

The flavonolignan derivative compound 4 was observed to be active against pathogenic microorganisms with a zone of inhibition represented in Table- 4 . Among the four concentrations used, both $25 \mu \mathrm{g} / \mathrm{ml}$ and $50 \mu \mathrm{g} / \mathrm{ml}$ of the sample showed an antimicrobial activity against the organisms. The higher concentrations of $75 \mu \mathrm{g} / \mathrm{ml}$ and $100 \mu \mathrm{g} / \mathrm{ml}$ maximum inhibition activity against E. coli (16 mm and $20 \mathrm{~mm}$ respectively) and B.subtilis (16 $\mathrm{mm}$ and $19 \mathrm{~mm}$ ). The isolated compound 4 showed the least activity against A.niger, while C.albicans was the most sensitive species (16 $\mathrm{mm}$ in $100 \mu \mathrm{g} / \mathrm{ml}$ concentration). The MIC value of flavonolignan derivative, the lowest MIC values $(>50 \mu \mathrm{g} / \mathrm{mL})$, was recorded against B.subtilis $P$. aeruginosa and E.coli. Then the moderate response of MIC was registered against S.aureus and C.albicans $(>75 \mu \mathrm{g} / \mathrm{mL})$. As suggested by previous reports, M. corchoifolia has been presented with numerous biological activities like Hepatoprotective antimicrobial. ${ }^{22}$ 


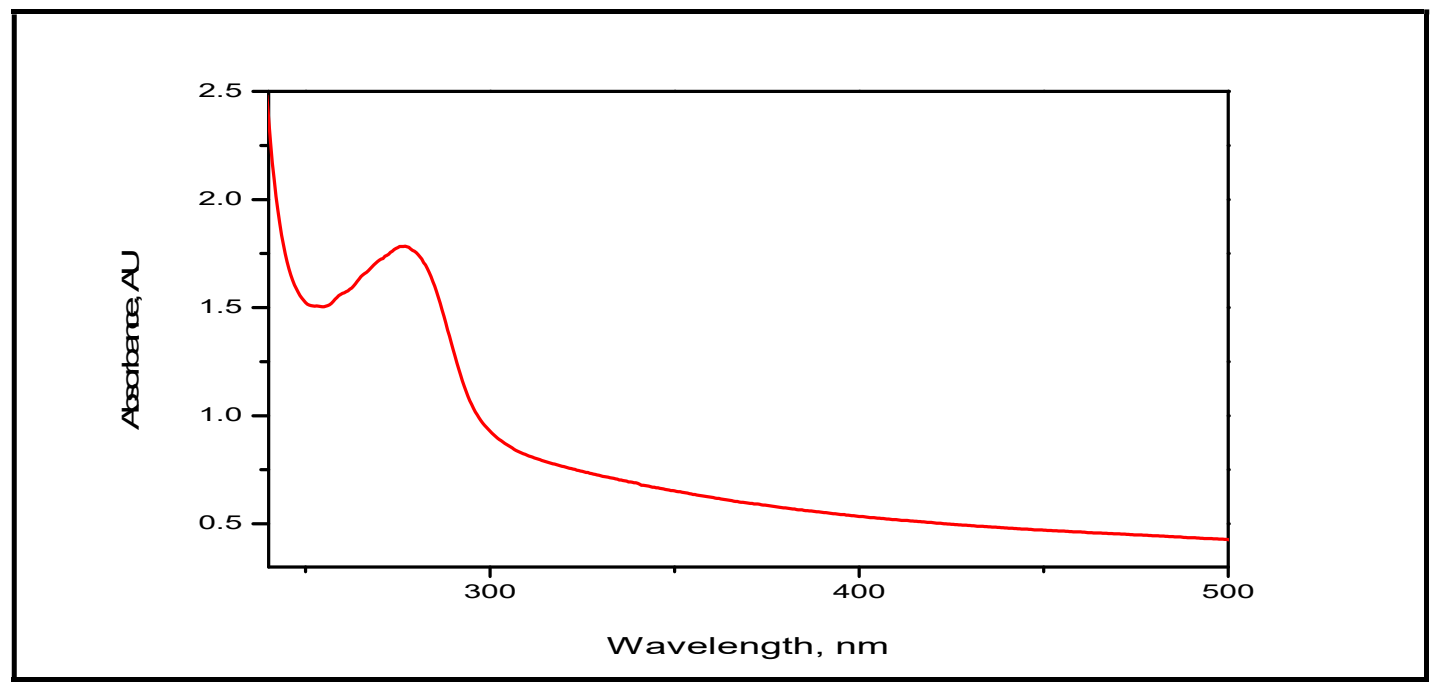

Fig.-11: UV-Vis Spectrum purified Flavonolignan Derivative

Table-4: Antibacterial and Antifungal Activity

\begin{tabular}{c|c|c|c|c|c|c}
\hline $\begin{array}{c}\text { Pathogenic } \\
\text { microorganism }\end{array}$ & $\begin{array}{c}30 \\
\text { STD }\end{array}$ & 25 & 50 & 75 & 100 & MIC \\
\hline E. coli & $25.32 \pm 0.05$ & $8.05 \pm 0.17$ & $10.23 \pm 0.03$ & $16.03 \pm 0.03$ & $20.33 \pm 0.14$ & $>50$ \\
\hline P. aeruginosa & $28.16 \pm 0.03$ & $0.00 \pm 0.00$ & $10.12 \pm 0.05$ & $12.98 \pm 0.25$ & $15.90 \pm 0.05$ & $>50$ \\
\hline B. subtilis & $20.25 \pm 0.05$ & $8.23 \pm 0.14$ & $14.16 \pm 0.03$ & $16.03 \pm 0.10$ & $19.10 \pm 0.15$ & $>50$ \\
\hline S. aureus & $20.13 \pm 0.14$ & $0.00 \pm 0.00$ & $08.56 \pm 0.06$ & $10.06 \pm 0.03$ & $12.16 \pm 0.03$ & $>75$ \\
\hline C.albicans & $19.45 \pm 0.03$ & $7.37 \pm 0.09$ & $08.24 \pm 0.09$ & $11.00 \pm 0.07$ & $16.42 \pm 0.14$ & $>75$ \\
\hline A. niger & $15.41 \pm 0.08$ & $0.00 \pm 0.00$ & $0.00 \pm 0.00$ & $08.06 \pm 0.03$ & $09.10 \pm 0.12$ & $>125$ \\
\hline \multicolumn{7}{l}{ Z Ztreptomycin; \# Clotrimazole } \\
\hline
\end{tabular}

\section{In-vitro Cytotoxicity Activity}

The cytotoxicity effect of the flavonolignan derivative compound 4 against suspension of adherent cell line (Breast cancer cell line MCF-7) is given in Table-5. Compound 4 showed an excellent anticancer reactivity against MCF-7 cell line. There was dose-dependent manner activity observed. MCF-7 cell lines showed a low level of cell viability (12.41\%) registered in $400 \mu \mathrm{g} / \mathrm{ml}$ at $48 \mathrm{~h}$, whereas $48 \mathrm{~h} \mathrm{MCF-7} \mathrm{cell}$ line showed a low level of cell viability registered $(94.27 \%)$ in $3.125 \mu \mathrm{g} / \mathrm{ml}$. The $\mathrm{IC}_{50}$ value of the isolated compound 4 was observed at $68.59 \mu \mathrm{g} / \mathrm{ml}$ against MCF-7. Another study has found that the flavonoids and phenolic compounds isolated from the extract of $M$. corchoifolia showed anticancer and cytotoxicity activities against HCT-116 and MCF-7 cells. ${ }^{23}$

Table- 5: Cytotoxicity Assay - MCF-7 Cell Line

\begin{tabular}{c|c}
\hline Concentrations $(\mu \mathrm{g} / \mathrm{ml})$ & Cell Viability $(\%)$ \\
\hline 0 & 100.00 \\
\hline 3.125 & 94.27 \\
\hline 6.25 & 83.85 \\
\hline 12.5 & 77.57 \\
\hline 25 & 59.82 \\
\hline 50 & 53.62 \\
\hline 100 & 38.58 \\
\hline 200 & 19.17 \\
\hline 400 & 12.41 \\
\hline IC50 & 68.59
\end{tabular}




\section{Docking Studies}

The ligand flavonolignan derivative compound 4 of M.corchorifolia is docked with Human Breast Cancer Estrogen Receptor protein (3EQM) and binding energy was determined. The isolated ligand compound 4 showed H-bond energy of -10.81 , the binding affinity of $-9.91 \mathrm{kcal} / \mathrm{mol}$ and the inhibition constant 988.69 $\mu \mathrm{m}$ Table-6. The potential binding site of amino acid residues of protein receptors is PHE147, LYS150, ALA151, SER153, PRO155, VAL158, ARG159 these amino acid residues act as strong binding region with the purified compound 4 Fig. $-12 .{ }^{24}$

Table-6: Binding Strength of Flavonolignan Ligand with the Protein Receptor (3EQM)

\begin{tabular}{c|c|c|c|c}
\hline Protein Pdb ID & Ligand & Hydrogen Bond & $\begin{array}{c}\text { Binding Energy } \\
(\mathrm{kcal} / \mathrm{mol})\end{array}$ & $\begin{array}{c}\text { Inhibition Constant } \\
(\mu \mathrm{m})\end{array}$ \\
\hline 3EQM & Flavonolignan & -10.81 & -9.91 & 988.69 \\
\hline
\end{tabular}

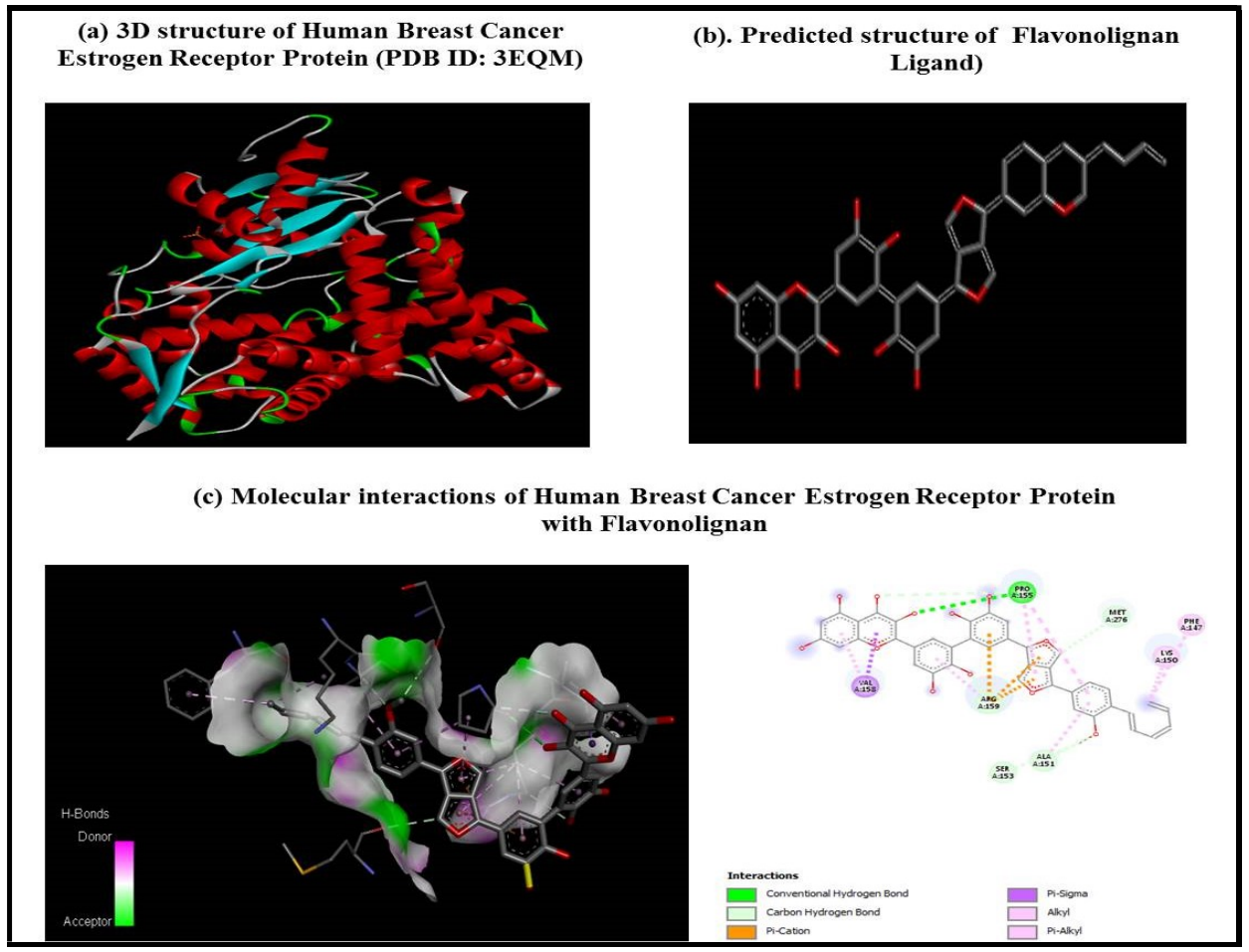

Fig.-12: Molecular Interaction of 3EQM with Flavonolignan Derivative Compound

\section{CONCLUSION}

The flavonolignan derivative compound 4 was isolated and separated from ethanol extract of Melochia corchorifolia leaf the compound possess both flavanone and lignan parts molecular formula $\mathrm{C}_{40} \mathrm{H}_{40} \mathrm{O}_{12}$, molecular name (2R,3R)-2-(5'-((1S,3aR,4S,6aR)-4-(4-(hex-5-en-1-yl)-3methoxyphenyl)hexahydrofuro[3,4-c]furan-1-yl)-2',3',5,6-tetrahydroxy-[1,1'-biphenyl]-3-yl)-3,5,7trihydroxychroman-4-one, are further characterized and confirmed through spectral analysis and by the Pubchem database structure similarity search possess $95 \%$ similarities with pseudotsuganol compound. In silico results, flavonolignan derivative compound 4 was docked with estrogen receptor protein, which showed stable interaction with the lowest binding energy $(-9.91 \Delta \mathrm{G}, \mathrm{kcal} / \mathrm{mol})$. The biological activities such as antimicrobial activity and anticancer activity of the flavonolignan derivative compound 4 showed promising effects. Moreover, there is a need for elaborated study on the biological aspects.

\section{ACKNOWLEDGEMENT}

We acknowledge DST-FIST (fund for the improvement of S\&T infrastructure) for financial assistance for the Department of Chemistry, SRM Institute of Science \& Technology, No.SR/FST/CST-266/2015(c). 
RASĀYAN J. Chem.

Vol. 14 | No. 3 |1669-1679| July - September | 2021

\section{REFERENCES}

1. S. Maria-Cristina Pranchevicius and R. Thiessa Vieira, Bioengineered, 4(5), 305(2013), https://doi.org/10.4161/bioe.24666

2. H. Ghazghazi, C. Aouadhi and M. Weslati, Journal of Essential Oil Bearing Plants, 18(3), 581(2015), https://doi.org/10.1080/0972060X.2014.905757

3. T. Pullaih, Ethnobotany, International Research Journal of Pharmacy, 5(7), 543(2014), https://doi.org/10.7897/2230-8407.0507109

4. M. N. Palaksha, K. Ravishankar and V. Girijasastry, International journal of Pharmacognosy, 4(7), 107(2017), https://doi.org/10.13040/IJPSR.0975-8232

5. R. Tschesche and I. Reutel, Tetrahedron Letters, 35(2), 3818(1968), https://doi.org/10.1016/s00404039(01)99

6. Muhammad Faisal, Asri Gani, A. R Nurul Hidayati, Putri Mardhatillah and H. Husni, Rasayan Journal of Chemistry, 14(2), 705(2021), https://doi.org/10.31788/RJC.2021.1426239

7. Smita Asthana, Sonia Chauhan and Satyanarayana Labani, Indian Journal of Public Health, 58(1), 5(2014), https://doi.org/10.4103/0019-557X.128150

8. A. Dalimunthe, P.Sitorus and D. Satria, Rasayan Journal of Chemistry, 14(3), 1447(2021), http://doi.org/10.31788/RJC.2021.1436161

9. M. Lippman, G. Bolan and K. Huff, Cancer Research, 36(12), 4595(1976), http://doi.org/10.1001/archotol.1994.01880350067012

10. Douglas B Kitchen, Hélène Decornez, John R Furr and Jürgen Bajorath, Nature Reviews Drug Discovery, 3(11), 935(2004), http://doi.org/10.1038/nrd1549

11. Ajay Singh, and Mansi Gupta, Rasayan Journal of Chemistry, 11(1), 228(2018), http://doi.org/10.7324/RJC.2018.1111999

12. R. Devika and J. Koilpillai, International Journal of Pharmaceutical Sciences and Research, 6(2), 762(2015), http://doi.org/10.13040/IJPSR.0975-8232.6

13. A. M. Hamil, K. M. Khalifa, A. AL-Houni and M. M. El-ajaily, Rasayan Journal of Chemistry, 2(2), 261(2009)

14. O. Atolani, C. B. Adeosun, A. P. Oluyori and J. Olota, Rasayan Journal of Chemistry, 12(3), 1052(2019), http://doi.org/10.31788/RJC.2019.1235122

15. H. Salomies, and J. P. Salo, Chromatographia, 36(1), 79(1993), http://doi.org/10.1007/bf02263842

16. Mamta Saxena, Jyoti Saxena, International Journal of Biological and Pharmaceutical Research, 3(3), 498(2012)

17. I. A. Holder and S. T. Boyce, Burns, 20(5), 426(1994), http://doi.org/10.1016/0305-4179(94)90035-3

18. N. S. Ghosh and R. Singh, Rasayan Journal of Chemistry, 14(1), 486(2021), http://doi.org/10.31788/RJC.2021.1416130

19. S. Sushma Murthy and T. Bala Narsaiah, Rasayan Journal of Chemistry, 12(4), 2030, (2019), http://doi.org/10.31788/RJC.2019.1245475

20. Lestyo Wulandari, Yuni Retnaningtyas, Nuri Hilmia Lukman, Journal of Analytical Methods in Chemistry, 12(1), 6(2016), http://doi.org/10.1155/2016/4696803

21. Lai Yeap Foo and Joseph Karchesy, Journal of the Chemical Society, Chemical Communications, 4(3), 219(1989), http://doi.org/10.1039/C39890000217

22. H. P. C. A. Cane, N. Saidi, M. Mustanir, D. Darusman, R. Idroes and M. Musman, Rasayan Journal of Chemistry, 13(4), 2215(2020), http://doi.org/10.31788/RJC.2020.1345818

23. A. L. Niles, R. A. Moravec, T. L. Riss, Expert Opinion on Drug Discovery, 3(6), 655(2008), http://doi.org/10.1517/17460441.3.6.655

24. Jeyabaskar Suganya, Mahendran Radha Devi, Asian Pacific Journal of Cancer Prevention, 15(19), 59(2014), http://doi.org/10.7314/apjcp.2014.15.19.8155

[RJC-6431/2021] 